
\title{
$\begin{array}{ll}\text { Research Square } & \text { Preprints are preliminary reports that have not undergone peer review. } \\ \text { They should not be considered conclusive, used to inform clinical practice, } \\ \text { or referenced by the media as validated information. }\end{array}$
}

\section{Gene therapy with hematopoietic stem and progenitor cell for monogenic disorders: a systematic review and meta-analysis}

Francesca Tucci

San Raffaele Telethon Institute for Gene Therapy (SR-Tiget), IRCCS San Raffaele Scientific Institute, Milan

Stefania Galimberti

Bicocca Bioinformatics Biostatistics and Bioimaging B4 Center, School of Medicine and Surgery, University of Milano - Bicocca, Monza

Luigi Naldini

San Raffaele Telethon Institute for Gene Therapy, IRCCS San Raffaele Scientific Institute, 20132 Milan (MI) https://orcid.org/0000-0002-7835-527X

Maria G Valsecchi

Interfant Trial Data

Alessandro Aiuti ( $\square$ aiuti.alessandro@hsr.it)

San Raffaele Telethon Institute for Gene Therapy (SR-Tiget), IRCCS San Raffaele Scientific Institute, Milan https://orcid.org/0000-0002-5398-1717

Article

Keywords: Ex-vivo hematopoietic stem and progenitor cell gene therapy, gamma-retroviral vectors, lentiviral vectors, genotoxicity

Posted Date: June 12th, 2021

DOI: https://doi.org/10.21203/rs.3.rs-596185/v1

License: (c) (7) This work is licensed under a Creative Commons Attribution 4.0 International License. Read Full License

Version of Record: A version of this preprint was published at Nature Communications on March 14th, 2022. See the published version at https://doi.org/10.1038/s41467-022-28762-2. 


\section{Abstract}

To provide an assessment of the safety of ex-vivo gene therapy (GT) with hematopoietic stem and progenitor cells (HSPC), we reviewed in a systematic manner the literature on monogenic diseases to describe survival, genotoxicity and engraftment of gene corrected HSPC, across vector platforms and diseases.

From 1995 to 2020, 55 trials for 14 diseases met inclusion criteria and 406 patients with primary immunodeficiencies (55.2\%), metabolic diseases (17.0\%), haemoglobinopathies (24.4\%) and bone marrow failures (3.4\%) were treated with gammaretroviral vector ( $\mathrm{RV}$ ) (29.1\%), self-inactivating $\gamma \mathrm{RV}$ (2.2\%) or lentiviral vectors (LV) (68.7\%). The pooled overall incidence rate of death was 0.9 per 100 person-years of observation $(\mathrm{PYO})(95 \% \mathrm{Cl}=0.37-2.17)$. There were 21 genotoxic events out of $1504.02 \mathrm{PYO}$. All these events occurred in YRV trials $(0.99$ events per $100 \mathrm{PYO}, 95 \% \mathrm{Cl}=0.18-5.43)$ for primary immunodeficiencies. Pooled rate of engraftment was $86.1 \%(95 \% \mathrm{Cl}=66.9-95.0 \%)$ for $\gamma \mathrm{RV}$ and $99.0 \%(95 \% \mathrm{Cl}=95.1-99.8 \%)$ for LV HSPC-GT $(p=0.002)$.

A comprehensive meta-analysis on HSPC-GT showed stable reconstitution of haematopoiesis in most recipients with superior engraftment and safer profile in patients receiving LV-transduced HSPC.

\section{Introduction}

In the past two decades, gene transfer into hematopoietic stem/progenitor cells (HSPC) has emerged as a promising treatment for several monogenic diseases, including primary immunodeficiencies (PID), metabolic disorders, haemoglobinopathies and bone marrow failures. Autologous HSPC gene therapy (GT), which belongs to the group of medicinal products classified as advanced therapies medicinal product (ATMP), is designed to overcome the main limitations related to allogeneic HSPC transplantation (HSCT), such as the availability of a compatible donor, the risk of graft versus host disease and need of post-HSCT immunosuppression, while providing comparable or sometime even superior therapeutic benefit. Recently three ATMPs based on HSPC-GT have been approved for the EU market for the treatment of Adenosine Deaminase Severe Combined Immunodeficiency (ADA-SCID), beta thalassemia and metachromatic leukodystrophy (MLD), respectively ${ }^{1}$. Other products are in advanced stage of development in the EU and US.

Engineered viral vectors integrate the therapeutic gene into the cromatin of the patients' own HSPC collected from the bone marrow or peripheral blood after mobilization. After reinfusion, gene corrected HSPC undergo self-renewal and transfer the healthy copy of the gene to daughter blood cells. GT works mainly through two mechanisms of action. In the case of PID and haemoglobinopathies, expression of the healthy gene restablishes normal differentiation and/or function of mature cells such as immune cells or red blood cells. For metabolic disorders, myeloid cells are engineered to express supraphysiological levels of the defective enzyme, which allows functional reconstitution of scavenger activity within various tissues and cross-correction of resident non-hematopoietic cells, including in the central nervous system ${ }^{1}$. The first integrating vectors to be employed were derived from gamma-retroviruses ( $\mathrm{RV}$ ). The limited gene transfer efficiency into HSPC and the occurrence of adverse events due insertional mutagenesis in $\mathrm{YRV}$ trials accelerated the development of self-inactivating lentiviral vectors (LV) as a delivery platform enabling more effective and safe insertion of therapeutic genes into HSPC.

Several excellent disease specific reviews have been published in this faster evolving area which however report the main results in descriptive manner, without providing cumulative analyses ${ }^{2,3}$. On the other hand, despite the requirement from national and EU regulatory bodies for active monitoring of delayed adverse events, the lack of centralization currently hampers a thorough and comprehensive collection of the long-term safety and efficacy data of HSPC-GT across various studies and platforms. Here we reviewed in a systematic manner the literature on monogenic diseases in the field of ex-vivo HSPC-GT with the aim to describe survival, genotoxicity and engraftment of gene corrected HSPC, across vector platforms and diseases, in a large cohort of patients over a period of 25 years. This meta-analysis helps providing a comprehensive picture of the current outcomes of these highly innovative treatments with the goal of informing scientific community, regulatory authorities and clinical practice.

\section{Results}

The results obtained from our search strategy are reported through the PRISMA flowchart in Fig. 1. From an initial selection of 10329 records from literature search and 127 from gray literature, 746 records were assessed for eligibility and a total of 55 studies, involving 406 patients, were considered. Overall, none of the studies included in the systematic review showed important methodological flaws as to be excluded from the meta-analysis (Supplementary text for detailed results and Supplementary Table 2 for data). The selected trials, performed from 1995 to 2020 , were all one-arm prospective studies and focused on the treatment of 14 different diseases by ex-vivo HSPC-GT (Table 1). LV was the most often used vector to genetically modify HSPC [34 trials (61.8\%) and 279 patients (68.7\%) and a total of 730.6 PYO], followed by YRV (20 trials and 118 patients, $36.4 \%$ and $29.1 \%$, respectively and a total of 807 PYO) and SIN-yRV (1 trial and 9 patients, $1.8 \%$ and $2.2 \%$, respectively and a total of 18.6 PYO). The use of LV was exclusive in trials of metabolic diseases ( $n=8,14.6 \%)$, Fanconi anemia (FA) $(n=3,5.5 \%)$ and hemoglobinopathies $(n=11,20 \%)$. In the PID group YRV was more frequently used $(n=20,36.4 \%)$ than LV $(n=12,21.8 \%)$ or SINYRV $(n=1,1.8 \%)$. The number of treated patients and the follow-up greatly varied across trials, ranging from one to 29 patients in sample size and 0.5 to 276.58 in total PYO, respectively. In 53 trials, where conditioning regimen was declared, 21 trials used a non-myeloablative regimen (10 YRV and 11 LV trials), 22 a myeloblative regimen ( 2 YRV and 20 LV trials), while no pre-GT conditioning was employed in 7 yRV, 3 LV and 1 SIN-yRV trials (Table 1). Two trials had > one regimen. The median CD34 + cell dose among trials ranged from 0.28 to $23.1 \times 10^{6} / \mathrm{kg}$. Overall, the median CD34 + cell dose infused was $8.95 \times 10^{6} / \mathrm{kg}$ (range 0.03-71) (260 available individual data) and median VCN/genome was 1.6 (range 0.05-9.4) (200 available data). 
Table 1

Characteristics of the 55 studies included in the meta-analysis

\begin{tabular}{|c|c|c|c|c|c|c|c|c|c|}
\hline Publication & Country & CT registration & Disease & $\begin{array}{l}\mathrm{N}^{\circ} \\
\text { Patients }\end{array}$ & Vector & Conditioning & $\begin{array}{l}\text { CD34+ } \\
* 10^{6} / \mathrm{kg} \\
\text { median } \\
(\min - \\
\max )\end{array}$ & $\begin{array}{l}\text { VCN } \\
\text { copies/genome } \\
\text { (min-max) }\end{array}$ & $\begin{array}{l}\text { Follow } \\
\text { up* in } \\
\text { month } \\
\text { (min- } \\
\text { max) }\end{array}$ \\
\hline $\begin{array}{l}\text { Candotti et } \\
\text { al. } .^{35}\end{array}$ & USA & NCT00018018 & ADA-SCID & 10 & gRV-ADA & N/S & $\begin{array}{l}1.9 \\
(0.7- \\
9.8)\end{array}$ & $0.1-1.46$ & $\begin{array}{l}30- \\
120\end{array}$ \\
\hline $\begin{array}{l}\text { Shaw et al. } \\
36\end{array}$ & USA & NCT00794508 & ADA-SCID & 10 & gRV-ADA & M & $\begin{array}{l}6.23 \\
(0.6- \\
8.4)\end{array}$ & $0.6-2.68$ & $42-84$ \\
\hline $\begin{array}{l}\text { Aiuti et al. } \\
37-40\end{array}$ & Italy & NCT00598481 & ADA-SCID & 22 & gRV-ADA & S & $\begin{array}{l}9.23 \\
(0.9- \\
18.5)\end{array}$ & $0.3-1.8$ & $\begin{array}{l}12.9- \\
241\end{array}$ \\
\hline Aiuti (PC)§ & Italy & $\begin{array}{l}\text { Compassionate } \\
\text { use }\end{array}$ & ADA-SCID & 2 & gRV-ADA & S & $\begin{array}{l}17.9 \\
(10.1- \\
25.7)\end{array}$ & 1.4 & $28-29$ \\
\hline $\begin{array}{l}\text { Migliavacca } \\
\text { et al. } 41\end{array}$ & Italy & NCT03478670 & ADA-SCID & 12 & gRV-ADA & S & $\begin{array}{l}11.55 \\
(3.4- \\
19.7)\end{array}$ & $1.2-2.5$ & $11-43$ \\
\hline Otsu et al. ${ }^{42}$ & Japan & - & ADA-SCID & 2 & gRV-ADA & $\mathrm{N}$ & $\begin{array}{l}1.15 \\
(0.92- \\
1.38)\end{array}$ & - & $\begin{array}{l}72- \\
120\end{array}$ \\
\hline $\begin{array}{l}\text { Gaspar et al. } \\
43\end{array}$ & UK & NCT01279720 & ADA-SCID & 6 & gRV-ADA & M & $\begin{array}{l}1.65- \\
0.5-5.8\end{array}$ & - & $24-84$ \\
\hline $\begin{array}{l}\text { Gaspar et al. } \\
44\end{array}$ & UK & - & ADA-SCID & 1 & gRV-ADA & S & 1.4 & - & 24 \\
\hline $\begin{array}{l}\text { Kohn et al. } \\
45,46\end{array}$ & USA & - & ADA-SCID & 3 & gRV-ADA & $\mathrm{N}$ & - & - & 180 \\
\hline $\begin{array}{l}\text { Braun et al. } \\
47,48\end{array}$ & Germany & DRKS00000330 & WAS & 10 & gRV-WAS & S & $\begin{array}{l}18.25 \\
(2.9- \\
24.9)\end{array}$ & $1.7-3.2$ & $15-86$ \\
\hline $\begin{array}{l}\text { Malech et } \\
\text { al. } 49\end{array}$ & USA & BB IND 6100 & $X-C G D$ & 5 & MFGS RV p47phox & $\mathrm{N}$ & $\begin{array}{l}2.5 \\
(0.1- \\
4.7)\end{array}$ & - & $\begin{array}{l}84- \\
120\end{array}$ \\
\hline Siler et al. ${ }^{50}$ & Switzerland & NCT00927134 & $X-C G D$ & 2 & gRV-CYBB & $S$ & $\begin{array}{l}5.65 \\
(5.3-6)\end{array}$ & $0.8-1.3$ & $\begin{array}{l}57.6- \\
87\end{array}$ \\
\hline Ott et al. ${ }^{51}$ & Germany & NCT00564759 & $X$-CGD & 2 & gRV-CYBB & S & $\begin{array}{l}4.35 \\
(3.6- \\
5.1)\end{array}$ & $1.5-2.6$ & $27-45$ \\
\hline $\begin{array}{l}\text { Kang et al. } \\
52\end{array}$ & USA & NCT00394316 & $X$-CGD & 3 & gRV-CYBB & $S$ & $\begin{array}{l}19 \\
(18.9- \\
71)\end{array}$ & $0.005-4.05$ & $11-36$ \\
\hline $\begin{array}{l}\text { Kang et al. } \\
53\end{array}$ & Korea & NCT00778882 & $X-C G D$ & 2 & gRV-CYBB & $S$ & $\begin{array}{l}5.6 \\
(5.4- \\
5.8)\end{array}$ & $0.5-2$ & 48 \\
\hline $\begin{array}{l}\text { Uchiyama et } \\
\text { al. } 54\end{array}$ & Japan & - & $X$-CGD & 1 & gRV-CYBB & - & 6.5 & 2.63 & 49 \\
\hline $\begin{array}{l}\text { Six; Ginn et } \\
\text { al. } 55-59\end{array}$ & $\begin{array}{l}\text { France; } \\
\text { Australia }\end{array}$ & - & X-SCID & 10 & gRV-IL-2Ry & $\mathrm{N}$ & $\begin{array}{l}5(1- \\
22)\end{array}$ & - & $8-180$ \\
\hline $\begin{array}{l}\text { Gaspar et al. } \\
60\end{array}$ & UK & & X-SCID & 10 & gRV-IL-2Ry & $\mathrm{N}$ & $\begin{array}{l}23.1 \\
(6.9- \\
34.1)\end{array}$ & - & $\begin{array}{l}51- \\
107\end{array}$ \\
\hline $\begin{array}{l}\text { Chinen et al. } \\
61\end{array}$ & USA & NCT00028236 & X-SCID & 3 & gRV-IL-2RY & $\mathrm{N}$ & $\begin{array}{l}2.92 \\
(2.85- \\
3.13)\end{array}$ & $1.1-3.7$ & $12-30$ \\
\hline
\end{tabular}

* when only one value was reported it refers to the median follow-up since min-max are missing. Individual medicinal products for the same disease (i.e. encoding the same transgene) may differ for vector backbone, promoter, vector production process and transduction method.

$\S$ Oral communications at 2020 ASCGT meeting. 


\begin{tabular}{|c|c|c|c|c|c|c|c|c|c|}
\hline Publication & Country & CT registration & Disease & $\begin{array}{l}\mathrm{N}^{\circ} \\
\text { Patients }\end{array}$ & Vector & Conditioning & $\begin{array}{l}\text { CD34+ } \\
* 10^{6} / \mathrm{kg} \\
\text { median } \\
(\min - \\
\text { max) }\end{array}$ & $\begin{array}{l}\text { VCN } \\
\text { copies/genome } \\
\text { (min-max) }\end{array}$ & $\begin{array}{l}\text { Follow } \\
\text { up in } \\
\text { month } \\
\text { (min- } \\
\text { max) }\end{array}$ \\
\hline \multirow{2}{*}{$\begin{array}{l}\text { Thrasher et } \\
\text { al. }{ }^{62}\end{array}$} & France; & \multirow[t]{2}{*}{-} & \multirow[t]{2}{*}{ X-SCID } & \multirow[t]{2}{*}{2} & \multirow[t]{2}{*}{ gRV-IL-2RY } & \multirow[t]{2}{*}{$N$} & \multirow{2}{*}{$\begin{array}{l}18.9 \\
(2.8- \\
35)\end{array}$} & \multirow[t]{2}{*}{ - } & \multirow[t]{2}{*}{6} \\
\hline & USA; UK & & & & & & & & \\
\hline $\begin{array}{l}\text { Gaspar et al. } \\
63\end{array}$ & UK & NCT01380990 & ADA-SCID & 5 & EFS-ADA LV & s & $4-11$ & $2.4-6.1$ & $5-19.7$ \\
\hline $\begin{array}{l}\text { Kohn et al. } \\
64\end{array}$ & USA & NCT01852071 & ADA-SCID & 20 & $\begin{array}{l}\text { SIN LV EF1aSprom- } \\
\text { ADA }\end{array}$ & S & - & - & 24 \\
\hline $\begin{array}{l}\text { Kohn et al. } \\
64\end{array}$ & USA & NCT02999984 & ADA-SCID & 10 & $\begin{array}{l}\text { SIN LV EF1aSprom- } \\
\text { ADA }\end{array}$ & $s$ & - & - & 24 \\
\hline $\begin{array}{l}\text { Scaramuzza } \\
\text { et al. } 20,65\end{array}$ & Italy & NCT02453477 & $\begin{array}{l}\beta- \\
\text { thalassaemia }\end{array}$ & 9 & GLOBE LV & M & $\begin{array}{l}19.5 \\
(16.3- \\
20)\end{array}$ & $0.7-1.5$ & $24-48$ \\
\hline $\begin{array}{l}\text { Cavazzana- } \\
\text { Calvo et } \\
\text { al. }{ }^{22}\end{array}$ & France & LG001 & thalassaemia & 2 & $\begin{array}{l}\text { SIN LV LCR- } \beta \text { prom- } \\
\beta \text {-globin }\end{array}$ & $M$ & 3.9 & 0.6 & $5-144$ \\
\hline $\begin{array}{l}\text { Thompson } \\
\text { et al. }{ }^{66}\end{array}$ & $\begin{array}{l}\text { USA; } \\
\text { Australia; } \\
\text { Thailand }\end{array}$ & NCT01745120 & $\begin{array}{l}\beta- \\
\text { thalassaemia }\end{array}$ & 18 & $\begin{array}{l}\text { LentiGlobin BB305 } \\
\text { vector }\end{array}$ & M & $\begin{array}{l}8.1 \\
(5.2- \\
18.1)\end{array}$ & $0.3-1.5$ & $\begin{array}{l}34.8- \\
61.3\end{array}$ \\
\hline $\begin{array}{l}\text { Thompson } \\
\text { et al. }{ }^{6} 6\end{array}$ & France & NCT02151526 & thalassaemia & 4 & $\begin{array}{l}\text { LentiGlobin BB305 } \\
\text { vector }\end{array}$ & M & $\begin{array}{l}10.5 \\
(8.8- \\
13.6)\end{array}$ & $0.8-2.1$ & $\begin{array}{l}40.5- \\
60.6\end{array}$ \\
\hline Lal et al. ${ }^{67}$ & Multisite & NCT03207009 & $\begin{array}{l}\beta- \\
\text { thalassaemia }\end{array}$ & 11 & $\begin{array}{l}\text { LentiGlobin BB305 } \\
\text { vector }\end{array}$ & M & - & $1.2-4.3$ & $2.5-21$ \\
\hline Colvin (PC)§ & & NCT02906202 & thalassaemia & 21 & $\begin{array}{l}\text { LentiGlobin BB305 } \\
\text { vector }\end{array}$ & M & - & - & $\begin{array}{l}0.9- \\
26.3\end{array}$ \\
\hline $\begin{array}{l}\text { Barshop } \\
(\mathrm{PC}) \S^{68}\end{array}$ & USA & NCT03897361 & Cystinosis & 1 & CTNSRD-04 & M & 7.88 & 2.07 & 6 \\
\hline AvroBio 69 & USA & FAB-201 & $\begin{array}{l}\text { Fabry } \\
\text { disease }\end{array}$ & 4 & AVR-RD-01 & $M$ & - & - & $1-1.83$ \\
\hline AvroBio 69 & Canada & NCT02800070 & $\begin{array}{l}\text { Fabry } \\
\text { disease }\end{array}$ & 5 & AVR-RD-01 & M & - & - & 2.67 \\
\hline $\begin{array}{l}\text { Adair et al. } \\
70\end{array}$ & USA & NCT01331018 & $\begin{array}{l}\text { Fanconi } \\
\text { anemia }\end{array}$ & 3 & $\begin{array}{l}\text { SIN LV PGKprom- } \\
\text { FANCA }\end{array}$ & $\mathrm{N}$ & $\begin{array}{l}0.03- \\
2.44\end{array}$ & $0.33-1.83$ & $\begin{array}{l}55.56- \\
60\end{array}$ \\
\hline $\begin{array}{l}\text { Rìo et al. } \\
71,72\end{array}$ & Spain & NCT03157804 & $\begin{array}{l}\text { Fanconi } \\
\text { anemia }\end{array}$ & 9 & $\begin{array}{l}\text { SIN LV PGKprom- } \\
\text { FANCA }\end{array}$ & $\mathrm{N}$ & $\begin{array}{l}(1.9- \\
7.3)\end{array}$ & $0.2-0.9$ & $2-3$ \\
\hline $\begin{array}{l}\text { Czechowicz } \\
\text { et al. }{ }^{73}\end{array}$ & USA & NCT03814408 & $\begin{array}{l}\text { Fanconi } \\
\text { anemia }\end{array}$ & 2 & $\begin{array}{l}\text { SIN LV PGKprom- } \\
\text { FANCA }\end{array}$ & $\mathrm{N}$ & $\begin{array}{l}0.28 \\
(0.2- \\
0.37)\end{array}$ & $2.08-2.21$ & 6 \\
\hline $\begin{array}{l}\text { Kohn et al. } \\
74\end{array}$ & USA & NCT03812263 & LAD & 1 & Chim-CD18-WPRE & S & 4.2 & 3.8 & 6 \\
\hline $\begin{array}{l}\text { Calbi et al. } \\
75-77\end{array}$ & Italy & NCT01560182 & MLD & 29 & $\begin{array}{l}\text { SIN LV PGKprom- } \\
\text { ARSA }\end{array}$ & M & $\begin{array}{l}10.5 \\
(3.2- \\
18.2)\end{array}$ & $1-7.4$ & 3-108 \\
\hline $\begin{array}{l}\text { Bernardo et } \\
\text { al. }{ }^{78}\end{array}$ & Italy & NCT03488394 & MPSIH & 8 & $\begin{array}{l}\text { SIN LV PGKprom- } \\
\text { IDUA }\end{array}$ & M & $\begin{array}{l}20.7 \\
(15- \\
29)\end{array}$ & $1-5.2$ & $3-18$ \\
\hline $\begin{array}{l}\text { Kinsella et } \\
\text { al. }{ }^{79}\end{array}$ & UK & & MPSIIIA & 1 & LV.CD11b.SGSH & M & 13.42 & 3.79 & 9 \\
\hline $\begin{array}{l}\text { Walters et } \\
\text { al. } 24\end{array}$ & USA & NCT02140554 & SCD & 7 & $\begin{array}{l}\text { LentiGlobin BB305 } \\
\text { vector }\end{array}$ & M & $\begin{array}{l}2.2 \\
(1.6- \\
5.1)\end{array}$ & $0.3-1.3$ & $\begin{array}{l}29.8- \\
44.5\end{array}$ \\
\hline
\end{tabular}




\begin{tabular}{|c|c|c|c|c|c|c|c|c|c|}
\hline Publication & Country & CT registration & Disease & $\begin{array}{l}\mathrm{N}^{\circ} \\
\text { Patients }\end{array}$ & Vector & Conditioning & $\begin{array}{l}\mathrm{CD} 34+ \\
* 10^{6} / \mathrm{kg} \\
\text { median } \\
(\min - \\
\max )\end{array}$ & $\begin{array}{l}\text { VCN } \\
\text { copies/genome } \\
\text { (min-max) }\end{array}$ & $\begin{array}{l}\text { Follow } \\
\text { up in } \\
\text { month } \\
\text { (min- } \\
\text { max) }\end{array}$ \\
\hline $\begin{array}{l}\text { Walters et } \\
\text { al. }{ }^{24}\end{array}$ & USA & NCT02140554 & SCD & 2 & $\begin{array}{l}\text { LentiGlobin BB305 } \\
\text { vector }\end{array}$ & M & $\begin{array}{l}2.7 \\
(2.2- \\
3.2)\end{array}$ & $1.4-5$ & $\begin{array}{l}17.2- \\
20.2\end{array}$ \\
\hline $\begin{array}{l}\text { Kanter et al. } \\
80\end{array}$ & USA & NCT02140554 & SCD & 17 & $\begin{array}{l}\text { LentiGlobin BB305 } \\
\text { vector }\end{array}$ & M & $\begin{array}{l}4.5(3- \\
8)\end{array}$ & $2.8-5.6$ & $1-20$ \\
\hline $\begin{array}{l}\text { Ribeil et al. } \\
81\end{array}$ & France & $\begin{array}{l}\text { NCT02151526; } \\
\text { NCT02633943 }\end{array}$ & $S C D$ & 3 & $\begin{array}{l}\text { LentiGlobin BB305 } \\
\text { vector }\end{array}$ & S & $\begin{array}{l}4.7(3- \\
5.6)\end{array}$ & $0.5-1.2$ & $\begin{array}{l}25.5- \\
52.5\end{array}$ \\
\hline $\begin{array}{l}\text { Esrick et al. } \\
82\end{array}$ & USA & NCT03282656 & SCD & 5 & BCH-BB694 & M & $3.3-8.3$ & $3.3-6.9$ & $1-18$ \\
\hline $\begin{array}{l}\text { Ferrua et al. } \\
19,83\end{array}$ & Italy & NCT01515462 & WAS & 17 & LVV-w1.6W WAS & $\mathrm{s}$ & $\begin{array}{l}12.2(7- \\
26.4)\end{array}$ & $0.9-4.3$ & 6-108 \\
\hline $\begin{array}{l}\text { Magnani et } \\
\text { al. }{ }^{84,85}\end{array}$ & $\begin{array}{l}\text { France; } \\
\text { UK }\end{array}$ & $\begin{array}{l}\text { NCT01347346; } \\
\text { NCT01347242 }\end{array}$ & WAS & 9 & LV-w1.6WASp & $\mathrm{s}$ & $\begin{array}{l}7.3(2- \\
15)\end{array}$ & $0.6-2.8$ & 7-109 \\
\hline $\begin{array}{l}\text { Morris et al. } \\
86\end{array}$ & UK & NCT01347242 & WAS & 1 & $\begin{array}{l}\text { LV-w1.6 WASp } \\
\text { vector }\end{array}$ & S & 3.77 & - & 20 \\
\hline $\begin{array}{l}\text { Labrosse et } \\
\text { al. }{ }^{87}\end{array}$ & USA & NCT01410825 & WAS & 5 & $\begin{array}{l}\text { w1.6_hWASP_WPRE } \\
\text { SIN-LV }\end{array}$ & $\mathrm{S} / \mathrm{M}$ & $\begin{array}{l}9.8 \\
(24.9- \\
6.3)\end{array}$ & $0.53-3.3$ & $\begin{array}{l}27.6- \\
68.4\end{array}$ \\
\hline $\begin{array}{l}\text { Eichler et al. } \\
88\end{array}$ & USA & NCT01896102 & X-ALD & 17 & $\begin{array}{l}\text { SIN LV MNDprom- } \\
\text { ABCD1 (Lenti-D) }\end{array}$ & M & $\begin{array}{l}10.5(6- \\
19.4)\end{array}$ & $0.5-2.5$ & $\begin{array}{l}21.6- \\
42\end{array}$ \\
\hline $\begin{array}{l}\text { Aubourg et } \\
\text { al. }{ }^{89,90}\end{array}$ & France & & X-ALD & 4 & $\begin{array}{l}\text { SIN LV MNDprom- } \\
\text { ABCD1 }\end{array}$ & M & - & - & $\begin{array}{l}60- \\
120\end{array}$ \\
\hline $\begin{array}{l}\text { Magnani et } \\
\text { al. }{ }^{91}\end{array}$ & France & NCT02757911 & $X-C G D$ & 4 & G1XCGD & - & - & $0.6-1.77$ & $5-40.8$ \\
\hline \multirow{2}{*}{$\begin{array}{l}\text { Kohn et al. } \\
92\end{array}$} & UK; & NCT01855685; & \multirow[t]{2}{*}{$X$-CGD } & \multirow[t]{2}{*}{9} & \multirow{2}{*}{$\begin{array}{l}\text { SIN LV } \\
\text { Chimericprom-CYBB }\end{array}$} & \multirow[t]{2}{*}{ M } & \multirow{2}{*}{$\begin{array}{l}12.5 \\
(6.5- \\
32.6)\end{array}$} & \multirow[t]{2}{*}{$0.7-5.5$} & \multirow[t]{2}{*}{$1-24$} \\
\hline & USA & NCT02234934 & & & & & & & \\
\hline $\begin{array}{l}\text { De Ravin et } \\
\text { al. }{ }^{93,94}\end{array}$ & USA & NCT01306019 & X-SCID & 5 & $\begin{array}{l}\text { SIN LV EF1aSprom- } \\
\text { IL-2RY }\end{array}$ & S & $\begin{array}{l}20.4 \\
(16- \\
25)\end{array}$ & - & $51-84$ \\
\hline $\begin{array}{l}\text { Mamcarz et } \\
\text { al. }{ }^{95,96}\end{array}$ & USA & NCT01512888 & X-SCID & 11 & $\begin{array}{l}\text { CL20-i4-EF1a-hyc- } \\
\text { OPT }\end{array}$ & S & $\begin{array}{l}8.7 \\
(4.5- \\
19)\end{array}$ & $0.16-1.13$ & $\begin{array}{l}1.5- \\
33.9\end{array}$ \\
\hline \multirow{2}{*}{$\begin{array}{l}\text { Hacein-Bey- } \\
\text { Abina et al. } \\
97\end{array}$} & France; & \multirow{2}{*}{$\begin{array}{l}\text { NCT01410019; } \\
\text { NCT01129544; } \\
\text { NCT01175239 }\end{array}$} & \multirow[t]{2}{*}{ X-SCID } & \multirow[t]{2}{*}{9} & SIN gRV & \multirow[t]{2}{*}{ N } & \multirow{2}{*}{$\begin{array}{l}7.8 \\
(3.7- \\
11.7)\end{array}$} & \multirow[t]{2}{*}{$0.25-2.92$} & \multirow[t]{2}{*}{$\begin{array}{l}12.1- \\
38.7\end{array}$} \\
\hline & USA & & & & EF1aSprom-IL-2Ry & & & & \\
\hline
\end{tabular}

* when only one value was reported it refers to the median follow-up since min-max are missing. Individual medicinal products for the same disease (i.e. encoding the same transgene) may differ for vector backbone, promoter, vector production process and transduction method.

$\S$ Oral communications at 2020 ASCGT meeting.

Abbreviations: PC: personal communication; N: no conditioning; M: myeloablative; S: submyeloablative/non-myeloablative.

There were 21 deaths reported in 12 trials over a total of 1556.04 PYO for a pooled estimate of the incidence rate of death of 0.90 events per $100 \mathrm{PYO}$ ( $95 \% \mathrm{Cl}$ $=0.37-2.17)$. The degree of heterogeneity among studies was moderately high, although non statistically significant $\left(I^{2}=49.4 \%, p=0.393\right)$. The incidence rates of death estimated in a meta-regression model were $1.01(95 \% \mathrm{Cl}=0.35-2.92)$ and $0.59(95 \% \mathrm{Cl}=0.16-2.90)$ per 100 PYO in patients treated with $\mathrm{LV}$ or YRV GT ( $p=0.423$ ) (Fig. 2). Similar results were obtained in the sensitivity analyses (Supplementary text).

The overall survival estimate at 5 years in 260 subjects with individual data (Supplementary Table 3) was 91.1\% (95\% Cl= 86.8-95.6\%) (Supplementary Fig. 1A) and similar for all vectors $(p=0.2652)$ (Supplementary Fig. $1 B$ ) and disease subgroups (PID, metabolic, haemoglobinopathies, FA; $p=0.7264)$ (Supplementary Fig. 1C). The survival profiles of the immunodeficiencies were significantly different $(p=0.0141)$ and ranged, at 5 years, from $100 \%$ for $A D A$ SCID to $78.8 \%(95 \% \mathrm{Cl}=61.2-100 \%)$ for X-CGD (Supplementary Fig. 1D). The causes of death were secondary to oncogenic events in 6 cases (5 related and 1 non related to GT), infectious and bleeding complications $(n=8)$, progressions of a neurodegenerative disorder $(n=4)$, ischemic stroke $(n=1)$, cardiovascular disease $(n=1)$ and not obtainable in one case (see Supplementary Table 4 describing the patients who died). The median time to event in 19 out of the 21 deaths was 1.83 years with a range of $0.08-5$ years (I-III quartiles $=0.46-3.7)$. No death occurred within 100 days from transplantation. The 21 events were 
observed in 13 patients treated with a LV (6 PID, 5 metabolic diseases, 2 hemoglobinopathies), 7 with a yRV (3 WAS, 2 X-CGD, 2 X-SCID) and 1 with a SIN-YRV (X-SCID).

Among the 406 patients treated, 21 genotoxic events were reported over a total of 1504.02 PYO for a pooled estimated incidence rate of 0.078 events per 100 PYO (95\% Cl=0.005-1.19). All the events occurred in 7 trials that used $\gamma R$ R, specifically in 9 WAS, 6 X-SCID, 5 X-CGD, and 1 ADA-SCID patients (460.6 PYO). The results of the meta-analysis indicated a very high and significant between-study heterogeneity $\left(I^{2}=87.7 \%, p<0.001\right)$ that was still confirmed when restricting the analyses to $\mathrm{YRV}$ trials $\left(\mathrm{I}^{2}=85.9 \%, \mathrm{p}<0.001\right)$. The pooled incidence rate obtained in this subgroup was 0.99 events per $100 \mathrm{PYO}(95 \% \mathrm{Cl}=0.18-$ 5.43). The forest plot of the trial specific incidence rates stratified by vector type is reported in Fig. 3 . The type of conditioning regimen did not result as a moderator in the meta-regression analysis $(p=0.602)$. All these results were robust to sensitivity analyses (Supplementary text).

The characteristics of 19 out of the 21 patients experiencing a genotoxic event are reported in Supplementary Table 5 . Their median age at gene-therapy was 3 years (min-max $=1$ months-27 years; 3 patients were adults), while the CD34 + cell dose and VCN mean values $( \pm \mathrm{sd})$ were $13.8 \times 10^{6} / \mathrm{kg}( \pm 7.1)$ and 2.4 copies/genome $( \pm 1.1)$, respectively. The median time to onset of genotoxic event was 2.8 years with a range of $0.7-14.8$ years $(I-I I I$ quartiles $=2.3-3.8)$. The most frequently targeted genes by oncogenesis-related $\gamma R V$ insertion sites were reported to be LMO2 (9 patients) and MECOM (6 patients, of whom 5 were XCGD). Twelve patients received an allogeneic HSCT after a median of 13.9 months from the occurrence of the genotoxic event (min-max $=3.2-24.7)$ and 4 subsequently died (median $=18.8$, min-max $=8.2-30$ months from the genotoxic event), while an additional patient died without HSCT.

The overall crude cumulative incidence of genotoxicity at 5 years from GT obtained from the available individual data was $9.6 \%(95 \% \mathrm{Cl}=5.9-15.5 \%)$ (Fig. 4A). When the estimation was done stratifying by vector type we obtained $17.3 \%(95 \% \mathrm{Cl}=11.0-27.3 \%)$ for $\mathrm{YRV}$, while no event was observed in LV and SIN-yRV subgroups $(p=0.0004)(F i g .4 B)$. The curves by disease within the $\gamma R V$ trials show at 5 years the lowest incidence in ADA-SCID $(2.7 \%, 95 \% C l=0.3-$ $19.2 \%)$ as compared to WAS $(66.7 \%, 95 \% \mathrm{Cl}=39.8-100.0 \%)$, X-CGD $(37.2,95 \% \mathrm{Cl}=17.6-78.4)$ and $\mathrm{X}-\mathrm{SCID}(20.6 \%, 95 \% \mathrm{Cl}=8.3-50.7 \%)$ and this difference was maintained overtime $(\mathrm{p}<0.0001)$ (Fig. 4C).

Out of the 395 patients included in the 54 trials with information available on engraftment, 361 displayed engraftment of gene corrected cells $\geq$ one year, with a pooled estimate of $96.9 \%(95 \% \mathrm{Cl}=91.1-98.9)$. The rate of engrafted patients was highly heterogeneous between studies $\left(\mathrm{I}^{2}=75.15 \%, \mathrm{p}<0.001\right)$ and the results of the regression model indicated that the nature of the viral vector was a significant moderator $(p=0.002)$. Only in 5 trials and 9 patients treated with a LV the engraftment was lost, while this happened in 11 trials and 24 patients using a $\gamma \mathrm{RV}$. The pooled rates of engraftment were $99.0 \%(95 \% \mathrm{Cl}=95.1-99.8 \%)$ and $86.1 \%(95 \% \mathrm{Cl}=66.9-95.0 \%)$ for LV and $\mathrm{RRV}$, respectively (Fig. 5). No major changes were observed in the results of the sensitivity analyses (Supplementary text).

\section{Discussion}

The purpose of HSPC-GT for monogenic disorders is to achieve permanent correction of long-term repopulating cells by integration of the therapeutic gene into the chromatin. Here, we gathered results from 55 studies including 406 participants, showing an extraordinary progress in the treament of genetic diseases in the past two decades. This meta-analysis provides relevant information on the safety of HSPC-GT across different vector platforms.

From the survival point of view, no death occurred within the first 100 days after GT. This represents a favourable finding compared to allogeneic HSCT that historically has been reported in the range of $7-20 \%$ in pediatric subjects ${ }^{4,5}$ and $6-14 \%$ in adolescent and adults ${ }^{6,7}$ due to toxicity, infections and acute GvHD. Of the 21 deaths reported, apart from those caused by genotoxicities, which were all derived from $Y R V$ trials, the others were mainly due to concomitant infections, progression of neurodegenerative disease or acute events not related to GT. The type of vector does not seem to be a moderator in the metaanalysis, since the three different vectors have a similar behavior in terms of survival. The overall survival at 5 years post GT was $91.1 \%$ without relevant differences among disease subgroups. In allogeneic HSCT, which represents the current standard of care for most diseases, the 5-year survival has been reported to be $74 \%$ for $\mathrm{PID}^{8}, 73 \%$ for $\mathrm{FA}^{9}, 59-95 \%$ for metabolic diseases ${ }^{10-12}$ such as MLD and MPSI respectively, and $91-92 \%$ for haemoglobinopathies ${ }^{13,14}$. Comparison between GT and allogeneic HSCT, however, was not the objective of this work and will require additional data collection and specific analyses. Registries of the European Society for Blood and Marrow Transplantation (EBMT) or the Center for International Blood and Marrow Transplant Research (CIBMTR) could represent a potential platform for comparing allogeneic HSCT and GT but currently are not designed to retrieve sufficiently high quality data for long-term monitoring and GT-related parameters.

Oncogenic events related to the insertional mutagenesis occurred in 21 patients over a total of 1504.02 PYO for a pooled overall incidence rate of 0.078 events per 100 PYO. Remarkably, $84 \%$ of oncogenic events occurred within the first five years post-GT, regardless of the type of disease, but the occurrence of one case 15 years after GT suggests that long-term follow-up should be implemented at least until this time point, in line with current EMA guidelines ${ }^{15}$. Postmarketing pharmacovigilance should be able to eventually capture signals deriving from HSPC-GT at longer time, even life-long.

The oncogenic events appear to be the results of a multistep process, in which the initial hit, in most cases an integration from a yRV vector near the $L M O 2$ gene activating its constitutive transcription, is followed by rearrangements, chromosomal translocations and other somatic mutations. Incidence of genotoxicity in YRV studies ranged from 0.20 events per 100 PYO in ADA-SCID patients to 26.6 events per 100 PYO in WAS patients. The different incidence among trials and diseases suggests that there are additional factors, including transgene function, disease background, vector dose, and individual genetic predisposition that influence the likelihood of occurrence of transformation. The molecular defect that causes inborn errors of immunity per se may predispose to tumorigenesis with variable degree, depending on the underlying molecular mechanisms ${ }^{16}$, together with an impaired tumor immune surveillance ${ }^{17}$. 
Unlike YRVs which contain strong retroviral enhancer and promoter elements (within the proviral long-terminal repeats; LTR) capable of transactivating of neighboring genes, LVs are designed with self-inactivating transcriptionally silent LTRs and often carry relatively weak or lineage-specific internal cellular promoters. These genetic features, together with different insertion site preferences from $\mathrm{RV}$, may provide a mechanistic explanation for the lack of reported malignant clonal expansion in LV trials. This observation substantiates with a robust clinical follow-up (730.7 PYO) the superior LV biosafety profile predicted by multiple non-clinical studies including in tumor prone mice ${ }^{18}$ and well correlates with the lack of clonal perturbation assessed by insertion site analyses in LV-based trials ${ }^{19-21}$. So far, only one patient in a LV trial for ß-thalassemia was reported to show a dominant clone harbouring an integration in the HMGA2 gene, causing deregulation of HMGA2 expression which, however, was not associated with adverse effects ${ }^{22}$. Very recently, a case of acute myeloid leukemia containing a viral integrant ${ }^{23}$ was described in a phase $1 / 2$ (HGB-206) study ${ }^{24}$ of LentiGlobin GT for sickle cell disease (SCD). Based on the available analyses, the sponsor has reported that the event is unlikely to be related to the BB305 LV23 and data are under review by EU and US regulatory authorities.

Emerging technology platforms based on targeted gene editing should in principle further reduce the residual potential low risk of insertional mutagenesis associated with genome-wide integration of $\mathrm{LVs}^{21,25,26}$. However, larger studies and longer follow-up are needed to carefully assess the clinical efficacy and safety of gene editing based approaches. The occurrence of a secondary tumor (myelodysplasia followed by leukemia) in one SCD patient treated with LV27, likely as a result of chemotherapy-induced mutagenesis on residual host cells as well as a bone marrow dysplasia observed in an ADA-SCID patient treated with YRV deriving from non-corrected cells ${ }^{28}$ were not unexpected. Indeed, the risk of secondary tumors is reported to be $4 \%$ at 7 years after autologous HSCT, with a median onset of 2.5 years post-transplantation (range $=3$ months-7 years). The risk may be higher in immunodeficient patients or in conditions characterized by hematopoietic stress and history of previous treatment with cytotoxic drugs, such as in SCD ${ }^{29}$. In this regard, replacement of standard chemotherapy with non genotoxic conditioning based on depleting antibodies or immunotoxins could reduce this risk ${ }^{30,31}$.

In the majority of patients, gene modified cells persisted long-term (> one year), indicating the ability of infused HSPC to engraft, self-renew and differentiate. We found that the nature of the vector represents a moderator of this parameter, confirming, so far in the clinical setting, the higher efficiency of LV in transducing repopulating hematopoietic stem cells. On the other hand, the selective advantage of functionally corrected cells in PID subjects may compensate for the the lower transduction when adopting the YRV platform.

Conversely, conditioning regimen had no role as moderator $(p=0.188)$. However, it should be considered that the infusion of corrected HSPC in absence of conditioning was mainly chosen for diseases in which a selective advantage for gene corrected lymphoid cells (SCID) or HSPC (FA) was expected and this could alleviate the need for a chemotherapy regimen.

The creation of a dedicated global registry will be instrumental to allow comprehensive analyses of the outcome of HSPC-GT across different diseases. At present, there is still debate on the optimal format of registries that could monitor long-term safety and efficacy of ATMP, in compliance to requests of regulatory authorities and payors. These registries could collect data on specific ATMPs or diseases but their accessibility could still be limited and there are known difficulties in harmonization between countries. Existing infrastructure such as the one used by EBMT could retrieve data on all HSPC-GT procedures and allow comparison with HSCT. This approach has been used to capture information on long-term follow-up of patients treated with CAR-T cells, but its success and broader applicability are still under evaluation ${ }^{32}$.

We are aware that our meta-analysis focused on several small trials, but this is a specificity of a therapeutic approach that has been almost entirely devoted until now to rare diseases and/or is still in its early phase of clinical development. Since follow-up is not homogeneously updated, we conducted a sensitivity analysis on studies with an adequate follow-up that confirmed our results. While we are confident that all genotoxic events up to date have been reported, some deaths might have been missed if not properly reported. We also recognize that engraftment is not a hard clinical endpoint for efficacy, but traditional efficacy endpoints are disease specific and this would have precluded the meta-analytic approach that combines all diseases. The creation of a dedicated global registry will be instrumental to allow comprehensive prospective meta-analyses of the outcome of HSPC-GT across different diseases. In conclusions, results from this meta-analysis summarizing two decades of studies on HSPC-GT in over 400 patients shows stable reconstitution of haematopoiesis with gene-corrected cells in most recipients and superior engraftment and safer genotoxic profile in patients receiving LV-transduced HSPC.

\section{Methods}

\section{Search Strategy and selection criteria}

In this systematic review and meta-analysis, we followed PRISMA guidelines. Searches were conducted in PubMed, Embase and Cochrane Central Register of Controlled Trials to identify potentially eligible literature from inception to October 2020. The search strategy used the following search terms in combination: "genetic disease" and "GT" or "ex-vivo GT", "autologous hematopoietic stem cell transplantation" or "HSPC-GT" (Supplementary text). We also handsearched the reference lists of every selected study and assessed relevant studies for further publications. A search on ClinicalTrials.gov was performed to identify potential missing trials from the original evaluations. Corresponding authors of selected publications were contacted to ask clarification and retrieve missing data. In addition, reviews, conference abstracts and oral communications were identified by electronic searching and included as "gray literature data". Abstracts of articles were then independently reviewed by two authors (AA and FT) and the full text was obtained for suitable articles. Data were also extracted independently.

To be eligible, studies must have: (1) included patients affected by monogenic inherited diseases treated with HSPC-GT; (2) reported outcomes, including numbers of deaths, genotoxicities and engraftments. Genotoxic events were intended as the first occurred haematological malignancy related or probably related to GT. Second malignancies and tumors not related to GT were not included in the genotoxicity analysis. Engraftment was considered successful when molecular tests reported the presence of gene corrected cells for $\geq 1$ year post-GT. Due to the lack of data, we did not performed a quantitative analysis of the engraftment on distinct hematopoietic lineages. Non clinical research and clinical studies on cancer or gene editing were excluded. Studies were also excluded

Page $7 / 16$ 
if they were limited to qualitative description. In addition to the target reported outcomes, the following variables were extracted: CT registration number, disease, type of vector, type of conditioning regimen, summary measures on infused CD34 + cells/kg, vector copy number (VCN/genome) on the drug product, duration of follow-up after GT and year at the latest update. When possible, individual data on age at treatment, infused CD34 + cells/kg, VCN/genome, occurred events, timing of any subsequent HSCT and duration of follow-up post-GT were also retrieved (see Supplementary text for more details). Individual medicinal products for the same disease (i.e. encoding the same transgene) may differ for vector backbone, promoter, vector production process and transduction method. The quality of the included studies was evaluated based on a six-item tool that assessed the selection and outcome domains (Supplementary Table 1) and was adapted from the The Newcastle-Ottawa Scale (NOS) for assessing the quality of non-randomised studies in metaanalysis $^{33}$. A global score ranging 0-15 (from lowest to highest quality) was also obtained from the six items. All studies meeting inclusion-exclusion criteria were independently evaluated by 2 trained authors (AA and FT).

\section{Data analysis}

The meta-analysis on the incidence rate of mortality and genotoxicity was conducted using a random intercept Poisson model, while the analysis on the rate of engraftment was performed by means of a random intercept logistic model ${ }^{34}$. The trial specific total exposures in terms of person-years of observation (PYO) were obtained from individual data or, when not available, from minimum, median and maximum follow-up. Heterogeneity across studies was graphically explored drawing forest plots and quantified by the $\mathrm{I}^{2}$ index, while the presence of heterogeneity was tested using the Cochran $\mathrm{Q}$ statistic. Summary results were reported along with their $95 \%$ Confidence Intervals $(\mathrm{Cl})$. P-values based on the likelihood ratio test were provided $(a=0.05$, two sided). $A$ sensitivity analysis was done by excluding those studies with a follow-up not fully adequate (i.e. median follow-up $<2$ years).

The available individual data were described in terms of survival by means of the Kaplan-Meyer estimator and comparisons were done by the log-rank test, while the Aalen-Johansen cumulative incidence curves were used to describe genotoxicity (with death as competing event) and the Gray test was used for comparisons. Estimates were reported with the corresponding $95 \% \mathrm{Cl}$. Analyses were performed using the software R version 3.6 (package metafor for the meta-analysis).

\section{Data availability}

Because this meta-analysis was based on data extracted from previously published research, most of the data and study materials are available in the public domain. Data from this additional analysis will not be made publicly available; however, we encourage interested parties to contact the corresponding author for further discussions.

\section{Declarations}

\section{Competing interests}

A.A. is PI of clinical trials sponsored by Orchard Therapeutics, which licensed gene therapy products for ADA-SCID, WAS, MLD, Beta-thalassemia, and MPS originally developed at SR-TIGET. A.A. is a member of Committee for Advanced Therapies (CAT) and his views are personal and may not be understood or quoted as being made on behalf of the European Medicines Agency (EMA). L.N. is an inventor on pending and issued patents on LV technology filed by the Salk Institute, Cell Genesys, Telethon Foundation, and/or San Raffaele Scientific Institute.

\section{Author contribution}

A.A. and S.G. conceived the study. F.T., S.G. and A.A. took responsibility for the integrity of the data and the accuracy of the analyses. F.T. and A.A. conducted the literature search, did the quality assessment of the selected studies and extracted data. F.T. and S.G. interpreted results and wrote the paper; S.G. and M.G.V. performed the statistical analysis; A.A., M.G.V. and L.N. critically revised the manuscript and helped with scientific discussion; A.A. contributed to interpretation and to the final writing of the paper. All the authors confirm they have full access to all the data in the study and accept responsibility to submit for publication.

\section{Acknowledgements}

The systematic review was financially supported by Fondazione Telethon, SR-TIGET core grant. The funders had no role in the design and conduct of the study; collection, management, analysis, and interpretation of the data; preparation, review, or approval of the manuscript; and decision to submit the manuscript for publication. We thank Drs. Juan A. Bueren, Fabio Candotti, Marina Cavazzana, Elizabeth M. Kang, Julie Kanter, Donald B. Kohn and Emmanuelle Six for their fruitful collaboration in providing useful information on specific clinical trials.

\section{References}

1. Ferrari G, Thrasher AJ, Aiuti A. Gene therapy using haematopoietic stem and progenitor cells. Nat Rev Genet 2020.

2. Tucci F, Scaramuzza S, Aiuti A, Mortellaro A. Update on Clinical Ex Vivo Hematopoietic Stem Cell Gene Therapy for Inherited Monogenic Diseases. Mol Ther 2020 .

3. Cavazzana M, Bushman FD, Miccio A, Andre-Schmutz I, Six E. Gene therapy targeting haematopoietic stem cells for inherited diseases: progress and challenges. Nat Rev Drug Discov 2019; 18(6): 447-62. 
4. Slatter MA, Rao K, Abd Hamid IJ, et al. Treosulfan and Fludarabine Conditioning for Hematopoietic Stem Cell Transplantation in Children with Primary Immunodeficiency: UK Experience. Biol Blood Marrow Transplant 2018; 24(3): 529-36.

5. Hassan A, Booth C, Brightwell A, et al. Outcome of hematopoietic stem cell transplantation for adenosine deaminase-deficient severe combined immunodeficiency. Blood 2012; 120(17): 3615-24; quiz 26.

6. Fox TA, Chakraverty R, Burns S, et al. Successful outcome following allogeneic hematopoietic stem cell transplantation in adults with primary immunodeficiency. Blood 2018; 131(8): 917-31.

7. Albert MH, Hauck F, Wiebking V, et al. Allogeneic stem cell transplantation in adolescents and young adults with primary immunodeficiencies. $J$ Allergy Clin Immunol Pract 2018; 6(1): 298-301 e2.

8. Pai SY, Logan BR, Griffith LM, et al. Transplantation outcomes for severe combined immunodeficiency, 2000-2009. N Engl J Med 2014; 371(5): 434-46.

9. Murillo-Sanjuan L, Gonzalez-Vicent M, Argiles Aparicio B, et al. Survival and toxicity outcomes of hematopoietic stem cell transplantation for pediatric patients with Fanconi anemia: a unified multicentric national study from the Spanish Working Group for Bone Marrow Transplantation in Children. Bone Marrow Transplant 2020.

10. Boucher AA, Miller W, Shanley R, et al. Long-term outcomes after allogeneic hematopoietic stem cell transplantation for metachromatic leukodystrophy: the largest single-institution cohort report. Orphanet J Rare Dis 2015; 10: 94.

11. Raymond GV, Aubourg P, Paker A, et al. Survival and Functional Outcomes in Boys with Cerebral Adrenoleukodystrophy with and without Hematopoietic Stem Cell Transplantation. Biol Blood Marrow Transplant 2019; 25(3): 538-48.

12. Aldenhoven $M$, Jones SA, Bonney D, et al. Hematopoietic cell transplantation for mucopolysaccharidosis patients is safe and effective: results after implementation of international guidelines. Biol Blood Marrow Transplant 2015; 21(6): 1106-9.

13. Strocchio L, Locatelli F. Hematopoietic Stem Cell Transplantation in Thalassemia. Hematol Oncol Clin North Am 2018; 32(2): 317-28.

14. Gluckman E, Cappelli B, Bernaudin F, et al. Sickle cell disease: an international survey of results of HLA-identical sibling hematopoietic stem cell transplantation. Blood 2017; 129(11): 1548-56.

15. https://.

16. Mayor PC, Eng KH, Singel KL, et al. Cancer in primary immunodeficiency diseases: Cancer incidence in the United States Immune Deficiency Network Registry. J Allergy Clin Immunol 2018; 141(3): 1028-35.

17. Hauck F, Gennery AR, Seidel MG. Editorial: The Relationship Between Cancer Predisposition and Primary Immunodeficiency. Front Immuno/ 2019; 10: 1781.

18. Montini E, Cesana D, Schmidt M, et al. The genotoxic potential of retroviral vectors is strongly modulated by vector design and integration site selection in a mouse model of HSC gene therapy. J Clin Invest 2009; 119(4): 964-75.

19. Ferrua F, Cicalese MP, Galimberti S, et al. Lentiviral haemopoietic stem/progenitor cell gene therapy for treatment of Wiskott-Aldrich syndrome: interim results of a non-randomised, open-label, phase 1/2 clinical study. Lancet Haematol 2019; 6(5): e239-e53.

20. Marktel S, Scaramuzza S, Cicalese MP, et al. Intrabone hematopoietic stem cell gene therapy for adult and pediatric patients affected by transfusiondependent ss-thalassemia. Nat Med 2019; 25(2): 234-41.

21. Bushman FD. Retroviral Insertional Mutagenesis in Humans: Evidence for Four Genetic Mechanisms Promoting Expansion of Cell Clones. Mol Ther 2020; 28(2): 352-6.

22. Cavazzana-Calvo M, Payen E, Negre $\mathrm{O}$, et al. Transfusion independence and HMGA2 activation after gene therapy of human beta-thalassaemia. Nature 2010; 467(7313): 318-22.

23. https://investor.bluebirdbio.com/news-releases/news-release-details/bluebird-bio-provides-updated-findings-reported-case-acute.

24. Walters MC TJ, Kwiatkowski JL, et al. Exploring the Drivers of Potential Clinical Benefit in Initial Patients Treated in the Hgb-206 Study of Lentiglobin for Sickle Cell Disease (SCD) Gene Therapy. Blood 2019: 2061

25. Palchaudhuri R, Saez B, Hoggatt J, et al. Non-genotoxic conditioning for hematopoietic stem cell transplantation using a hematopoietic-cell-specific internalizing immunotoxin. Nat Biotechnol 2016; 34(7): 738-45.

26. Kwon HS, Logan AC, Chhabra A, et al. Anti-human CD117 antibody-mediated bone marrow niche clearance in nonhuman primates and humanized NSG mice. Blood 2019; 133(19): 2104-8.

27. Hsieh MM BM, Pierciey FJ, Uchida N, Rottman J, Demopoulos L, Manfred Schmidt M, Kanter J, Walters MC, Thompson AA, Asmal M, Tisdale JF. Myelodysplastic syndrome unrelated to lentiviral vector in a patient treated with gene therapy for sickle cell disease. Blood Advances 2020; 4(9): 205863.

28. Sokolic R, Maric I, Kesserwan C, et al. Myeloid dysplasia and bone marrow hypocellularity in adenosine deaminase-deficient severe combined immune deficiency. Blood 2011; 118(10): 2688-94.

29. Regan S, Yang X, Finnberg NK, El-Deiry WS, Pu JJ. Occurrence of acute myeloid leukemia in hydroxyurea-treated sickle cell disease patient. Cancer Biol Ther 2019; 20(11): 1389-97.

30. Aiuti A, Naldini L. Safer conditioning for blood stem cell transplants. Nat Biotechnol 2016; 34(7): 721-3.

31. Agarwal R DC, Prohaska S, Long-Boyle J, Kwon H, Brown JM, Weinberg JK, Le A, Guttman-Klein A, Logan AC, Weissman IL, Digiusto D, Cowan MJ, Parkman R, Roncarolo MG, Shizuru JA. Toxicity-Free Hematopoietic Stem Cell Engraftment Achieved with Anti-CD117 Monoclonal Antibody Conditioning. Biol Blood Marrow Transplant 2019; 25(3): S92. 
32. McGrath E, Chabannon C, Terwel S, Bonini C, Kuball J. Opportunities and challenges associated with the evaluation of chimeric antigen receptor T cells in real-life. Curr Opin Oncol 2020; 32(5): 427-33.

33. http://www.ohri.ca/programs/clinical_epidemiology/oxford.asp.

34. Stijnen T, Hamza TH, Ozdemir P. Random effects meta-analysis of event outcome in the framework of the generalized linear mixed model with applications in sparse data. Stat Med 2010; 29(29): 3046-67.

35. Candotti F, Shaw KL, Muul L, et al. Gene therapy for adenosine deaminase-deficient severe combined immune deficiency: clinical comparison of retroviral vectors and treatment plans. Blood 2012; 120(18): 3635-46.

36. Shaw KL, Garabedian E, Mishra S, et al. Clinical efficacy of gene-modified stem cells in adenosine deaminase-deficient immunodeficiency. J Clin Invest 2017; 127(5): 1689-99.

37. Aiuti A, Slavin S, Aker M, et al. Correction of ADA-SCID by stem cell gene therapy combined with nonmyeloablative conditioning. Science 2002; 296(5577): 2410-3.

38. Aiuti A, Cattaneo F, Galimberti S, et al. Gene therapy for immunodeficiency due to adenosine deaminase deficiency. N Engl J Med 2009; 360(5): 447-58.

39. Cicalese MP, Ferrua F, Castagnaro L, et al. Update on the safety and efficacy of retroviral gene therapy for immunodeficiency due to adenosine deaminase deficiency. Blood 2016; 128(1): 45-54.

40. Barzaghi F, Migliavacca, M, Fossati, C, Recupero, S, Pajno, R, Giannelli, S, et al.. Ex Vivo Retroviral Gene Therapy For The Treatment Of Severe Combined Immunodeficiency Due To Adenosine Deaminase Deficiency (ADA-SCID): Long-Term (Up To 18 Years) Follow-Up. 19th Biennial Meeting of The European Society for Immunodeficiencies Online meeting 2020.

41. Migliavacca M, Barzaghi, F, Fossati, C, Garella, V, Dionisio, F, Giannelli, S, et al.. Experience With The First Approved Commercial Gene Therapy For The Treatment Of Severe Combined Immunodeficiency Due To Adenosine Deaminase Deficiency (ADA-SCID). 19th Biennial Meeting of The European Society for Immunodeficiencies Online meeting 2020.

42. Otsu M, Yamada M, Nakajima S, et al. Outcomes in two Japanese adenosine deaminase-deficiency patients treated by stem cell gene therapy with no cytoreductive conditioning. J Clin Immunol 2015; 35(4): 384-98.

43. Gaspar HB, Cooray S, Gilmour KC, et al. Hematopoietic stem cell gene therapy for adenosine deaminase-deficient severe combined immunodeficiency leads to long-term immunological recovery and metabolic correction. Sci Transl Med 2011; 3(97): 97ra80.

44. Gaspar HB, Bjorkegren E, Parsley K, et al. Successful reconstitution of immunity in ADA-SCID by stem cell gene therapy following cessation of PEG-ADA and use of mild preconditioning. Mol Ther 2006; 14(4): 505-13.

45. Kohn DB, Hershfield MS, Carbonaro D, et al. T lymphocytes with a normal ADA gene accumulate after transplantation of transduced autologous umbilical cord blood CD34 + cells in ADA-deficient SCID neonates. Nat Med 1998; 4(7): 775-80.

46. Schmidt M, Carbonaro DA, Speckmann C, et al. Clonality analysis after retroviral-mediated gene transfer to CD34 + cells from the cord blood of ADAdeficient SCID neonates. Nat Med 2003; 9(4): 463-8.

47. Boztug K, Schmidt M, Schwarzer A, et al. Stem-cell gene therapy for the Wiskott-Aldrich syndrome. N Engl J Med 2010; 363(20): 1918-27.

48. Braun CJ, Boztug K, Paruzynski A, et al. Gene therapy for Wiskott-Aldrich syndrome-long-term efficacy and genotoxicity. Sci Trans/ Med 2014; 6(227): 227 ra33.

49. Malech HL, Maples PB, Whiting-Theobald N, et al. Prolonged production of NADPH oxidase-corrected granulocytes after gene therapy of chronic granulomatous disease. Proc Natl Acad Sci U S A 1997; 94(22): 12133-8.

50. Siler U, Paruzynski A, Holtgreve-Grez H, et al. Successful Combination of Sequential Gene Therapy and Rescue Allo-HSCT in Two Children with X-CGD Importance of Timing. Curr Gene Ther 2015; 15(4): 416-27.

51. Ott MG, Schmidt M, Schwarzwaelder K, et al. Correction of X-linked chronic granulomatous disease by gene therapy, augmented by insertional activation of MDS1-EVI1, PRDM16 or SETBP1. Nat Med 2006; 12(4): 401-9.

52. Kang EM, Choi U, Theobald N, et al. Retrovirus gene therapy for X-linked chronic granulomatous disease can achieve stable long-term correction of oxidase activity in peripheral blood neutrophils. Blood 2010; 115(4): 783-91.

53. Kang HJ, Bartholomae CC, Paruzynski A, et al. Retroviral gene therapy for X-linked chronic granulomatous disease: results from phase I/II trial. Mol Ther 2011; 19(11): 2092-101.

54. Uchiyama T KT, Nakabayashi K, et al.. Insertional Oncogenesis in X-CGD Patient after MFGS Retroviral Vector-Mediated Gene Therapy. Molecular Therapy 2019; 27.

55. Hacein-Bey-Abina S, Von Kalle C, Schmidt M, et al. LMO2-associated clonal T cell proliferation in two patients after gene therapy for SCID-X1. Science 2003; 302(5644): 415-9.

56. Hacein-Bey-Abina S, Garrigue A, Wang GP, et al. Insertional oncogenesis in 4 patients after retrovirus-mediated gene therapy of SCID-X1. J Clin Invest 2008; 118(9): 3132-42.

57. Hacein-Bey-Abina S, Hauer J, Lim A, et al. Efficacy of gene therapy for X-linked severe combined immunodeficiency. N Eng/ J Med 2010; 363(4): 355-64.

58. Ginn SL, Curtin JA, Kramer B, et al. Treatment of an infant with X-linked severe combined immunodeficiency (SCID-X1) by gene therapy in Australia. Med J Aust 2005; 182(9): 458-63.

59. Six E GV, Magnani A, et al. LMO2 Associated Clonal T Cell Proliferation 15 Years After Gamma-Retrovirus Mediated Gene Therapy for SCIDX1. Molecular Therapy 2017; 25 
60. Gaspar HB, Cooray S, Gilmour KC, et al. Long-term persistence of a polyclonal T cell repertoire after gene therapy for X-linked severe combined immunodeficiency. Sci Transl Med 2011; 3(97): 97ra79.

61. Chinen J, Davis J, De Ravin SS, et al. Gene therapy improves immune function in preadolescents with X-linked severe combined immunodeficiency. Blood 2007; 110(1): 67-73.

62. Thrasher AJ, Hacein-Bey-Abina S, Gaspar HB, et al. Failure of SCID-X1 gene therapy in older patients. Blood 2005; 105(11): 4255-7.

63. Gaspar HB BK, Rivat C, et al. Immunological and Metabolic Correction After Lentiviral Vector Mediated Haematopoietic Stem Cell Gene Therapy for ADA Deficiency. Molecular Therapy 2014; 22.

64. Kohn DB KLSK, Garabedian E, et al. Lentiviral Gene Therapy with Autologous Hematopoietic Stem and Progenitor Cells (HSPCs) for the Treatment of Severe Combined Immune Deficiency Due to Adenosine Deaminase Deficiency (ADA-SCID): Two Year Follow-Up Results. Molecular Therapy $2020 ; 28$.

65. Scaramuzza S MS, Giglio F et al.. Clinical Outcomes from a Phase I/II Gene Therapy Trial for Patients affected by Severe Transfusion Dependent BetaThalassemia: Two Years Follow Up. Molecular Therapy 2020; 28.

66. Thompson AA, Walters MC, Kwiatkowski J, et al. Gene Therapy in Patients with Transfusion-Dependent beta-Thalassemia. N Engl J Med 2018; 378(16): 1479-93.

67. Lal A LF, Kwiatkowski JL, et al.. Northstar-3: Interim Results from a Phase 3 Study Evaluating Lentiglobin Gene Therapy in Patients with TransfusionDependent $\beta$-Thalassemia and Either a $\beta 0$ or IVS-I-110 Mutation at Both Alleles of the HBB Gene. Blood 2019; $134: 815$.

68. Barshop B BE, Dohil M, et al.. Hematopoietic Stem Cell Gene Therapy for Cystinosis: Initial Results from a Phase I/II Clinical Trial. Molecular Therapy 2020; 28.

69. https://investors.avrobio.com/static-files/1367a559-cc62-4d0c-bc21-df77bc5143ec.

70. Adair JE, Sevilla J, Heredia CD, Becker PS, Kiem HP, Bueren J. Lessons Learned from Two Decades of Clinical Trial Experience in Gene Therapy for Fanconi Anemia. Curr Gene Ther 2017; 16(5): 338-48.

71. Rio P, Navarro S, Wang W, et al. Successful engraftment of gene-corrected hematopoietic stem cells in non-conditioned patients with Fanconi anemia. Nat Med 2019; 25(9): 1396-401.

72. Río P NS, Sánchez-Domínguez R et al.. Updated Results of a European Gene Therapy Trial in Fanconi Anemia Patients, Subtype A Molecular Therapy 2020; 28.

73. Czechowicz A RP, Bueren J et al.. Changing the Natural History of Fanconi Anemia Complementation Group-À with Gene Therapy: Early Results of U.S. Phase I Study of Lentiviral-Mediated Ex-Vivo FANCA Gene Insertion in Human Stem and Progenitor Cells. Biol Blood Marrow Transplant $2020 ; 26$.

74. Kohn DB RG, Almarza E et al.. Phase 1/2 Study of Lentiviral-Mediated Ex-Vivo Gene Therapy for Pediatric Patients with Severe Leukocyte Adhesion Deficiency-I (LAD-I): Initial Results from the First Treated Patient. Molecular Therapy 2020; 28.

75. Biffi A, Montini E, Lorioli L, et al. Lentiviral hematopoietic stem cell gene therapy benefits metachromatic leukodystrophy. Science 2013; 341(6148): 1233158.

76. Sessa M, Lorioli L, Fumagalli F, et al. Lentiviral haemopoietic stem-cell gene therapy in early-onset metachromatic leukodystrophy: an ad-hoc analysis of a non-randomised, open-label, phase 1/2 trial. Lancet 2016; 388(10043): 476-87.

77. Fumagalli F CV, Sessa M, Baldoli C, Rancoita PVM, Acquati S, De Mattia F, Tucci F, Gallo V, Zancan S, Montini E, Segovia J, Schwab LC, Downey G, Sharpe J, Gabaldo M, Martino S, Di Serio C, Ciceri F, Filippi M, Natali Sora MG, Bernardo ME, Naldini L, Biffi A, Aiuti A.. Lentiviral hematopoietic stem and progenitor cell gene therapy (HSPC-GT) for metachromatic leukodystrophy (MLD): Clinical outcomes from 33 patients. 16th Annual WORLD Symposium, Orlando USA; 2020.

78. Bernardo ME GB, Tucci F, Fumagalli F, Ciotti F, Sarzana M, Pontesilli S, Baldoli C, Darin S, De Bellis D, Miglietta S, Zonari E, Parini R, La Marca G, Naldini L, Aiuti A. First-in-human phase I/II clinical trial of hematopoietic stem cell-gene therapy for Mucopolysaccharidosis type I, Hurler (MPS-IH): preliminary evidence of extensive metabolic correction. $25^{\circ}$ virtual EHA Annual Meeting; 2020.

79. Kinsella J BK, Church H, Duran-Jimenez B, Lee H, Ellison S, Vaz F, Wijburg F, Farzaneh F, Jones S, Thrasher A, Wynn R, Bigger BW. Preliminary outcomes of haematopoietic stem cell gene therapy in a patient with Mucopolysaccharidosis IIIA Molecular Therapy 2020; 28.

80. Tisdale JF KJ, Mapara MY et al.. Resolution of Sickle Cell Disease (SCD) Manifestations in Patients Treated with Lentiglobin Gene Therapy: Updated Results from the Phase 1/2 HGB-206 Group C Study. Molecular Therapy 2020; 28.

81. Ribeil JA, Hacein-Bey-Abina S, Payen E, et al. Gene Therapy in a Patient with Sickle Cell Disease. N Engl J Med 2017; 376(9): 848-55.

82. Esrick EB AM, Armant M, Bartolucci P, Ciuculescu MF, Daley H, Dansereau C, et al. Validation of BCL11A As Therapeutic Target in Sickle Cell Disease: Results from the Adult Cohort of a Pilot/Feasibility Gene Therapy Trial Inducing Sustained Expression of Fetal Hemoglobin Using Post-Transcriptional Gene Silencing. Blood 2019; 134

83. Aiuti A, Biasco L, Scaramuzza S, et al. Lentiviral hematopoietic stem cell gene therapy in patients with Wiskott-Aldrich syndrome. Science 2013; 341(6148): 1233151.

84. Hacein-Bey Abina S, Gaspar HB, Blondeau J, et al. Outcomes following gene therapy in patients with severe Wiskott-Aldrich syndrome. JAMA 2015; 313(15): 1550-63.

85. Magnani A AF, Semeraro M et al. Long-Term Follow-Up Study after Lentiviral Hematopoietic Stem/Progenitor Cell Gene Therapy for Wiskott-Aldrich Syndrome. Molecular Therapy 2020; 28.

86. Morris EC, Fox T, Chakraverty R, et al. Gene therapy for Wiskott-Aldrich syndrome in a severely affected adult. Blood 2017; 130(11): 1327-35.

87. Labrosse R CJ, Armant M, et al. Outcome of Hematopoietic Stem Cell Gene Therapy for Wiskott-Aldrich Syndrome. Blood $2019 ; 134: 4629$.

Page $11 / 16$ 
88. Eichler F, Duncan C, Musolino PL, et al. Hematopoietic Stem-Cell Gene Therapy for Cerebral Adrenoleukodystrophy. N Eng/ J Med 2017; 377(17): 1630-8.

89. Cartier N, Hacein-Bey-Abina S, Bartholomae CC, et al. Hematopoietic stem cell gene therapy with a lentiviral vector in X-linked adrenoleukodystrophy. Science 2009; 326(5954): 818-23.

90. Aubourg P AC, Dufayet G, et al.. Continuing Clinical Efficacy and ALDP Gene Expression 5-10 Years after Lentiviral LV-Based CD34 + Cell Gene Therapy in Patients with X-linked Adrenoleukodystrophy (X-ALD). Molecular Therapy 2020; 28.

91. Magnani A SS, Cousin C, et al.. Results from a Phase I/II Clinical Trial for X Linked Chronic Granulomatous Disease (CGD): Possible Impact of Inflammation on Gene Therapy Efficacy. Molecular Therapy 2020; 28.

92. Kohn DB, Booth C, Kang EM, et al. Lentiviral gene therapy for X-linked chronic granulomatous disease. Nat Med 2020; 26(2): 200-6.

93. De Ravin SS, Wu X, Moir S, et al. Lentiviral hematopoietic stem cell gene therapy for X-linked severe combined immunodeficiency. Sci Trans/ Med 2016; 8(335): 335ra57.

94. De Ravin SS OBS, Kwatemaa N, et al.. Enhanced Transduction Lentivector Gene Therapy for Treatment of Older Patients with X-Linked Severe Combined Immunodeficiency. Blood 2019; 134: 608.

95. Mamcarz E, Zhou S, Lockey T, et al. Lentiviral Gene Therapy Combined with Low-Dose Busulfan in Infants with SCID-X1. N Engl J Med 2019; 380(16): 1525-34.

96. Mamcarz E ZS, Lockey T et al. Lentiviral Gene Therapy with Low Dose Busulfan for Infants with X-SCID Results in the Development of a Functional Normal Immune System: Interim Results of an Ongoing Phase I/II Clinical Study Blood 2019; 134: 608.

97. Hacein-Bey-Abina S, Pai SY, Gaspar HB, et al. A modified gamma-retrovirus vector for X-linked severe combined immunodeficiency. N Engl J Med 2014; 371(15): 1407-17.

\section{Figures}

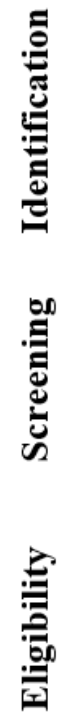

를
10329 Records identified through literature search of MEDLINE, Embase and Cochrane
127 References of articles meeting inclusion criteria or gray literature search for online reports

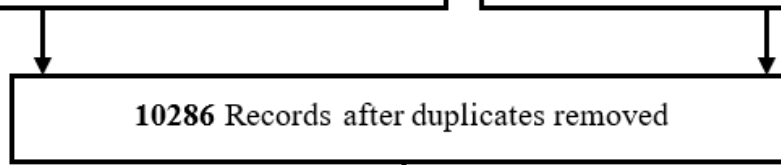

9541 Records excluded based on the title and abstract review

653 Full-text articles excluded:

745 Full-text articles assessed for eligibility

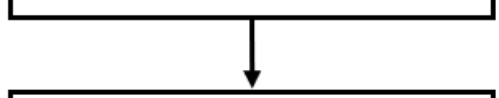

55 Studies included in qualitative synthesis and metaanalysis
- 495 reviews

- 50 preclinical studies

- 48 editorials/comments

- 36 non English language articles

- 11 qualitative/ postmarketing reports

- 9 could not be retrieved

- 3 other ex-vivo gene therapy studies (with lymphocytes)

- 1 in vivo GT studies

Figure 1

Study selection 


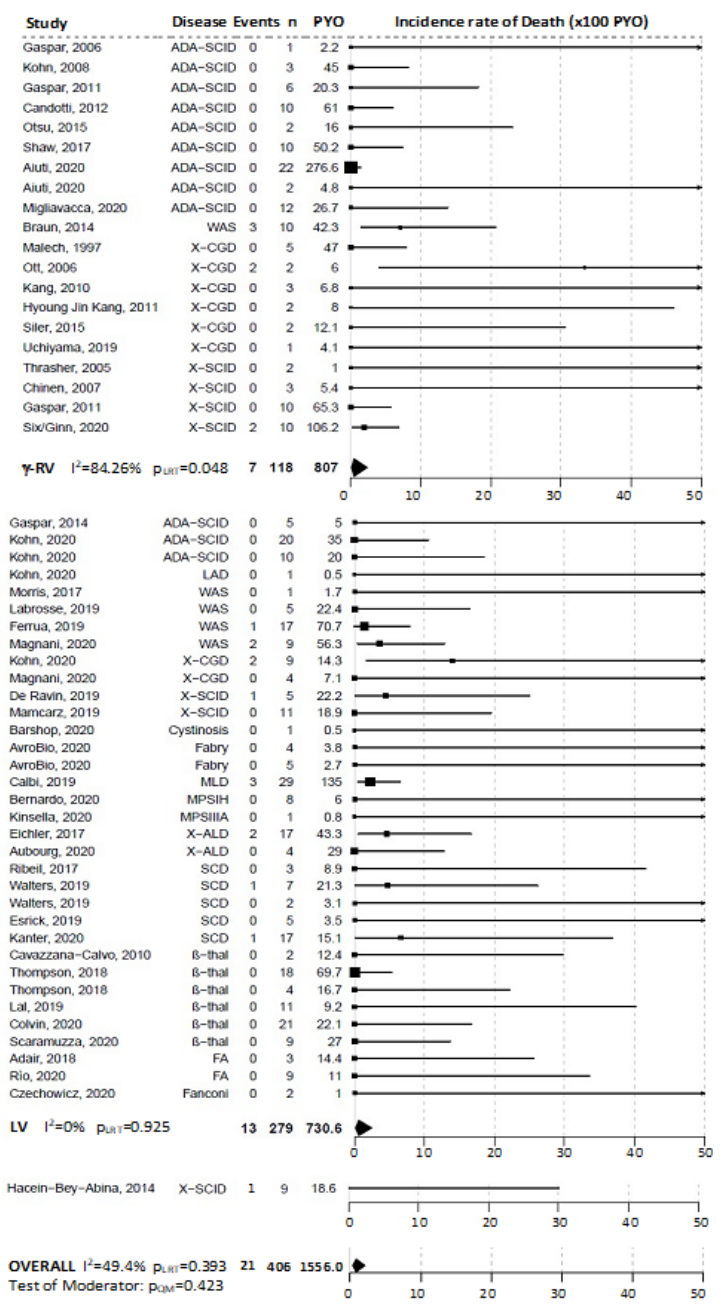

\section{Figure 2}

Forest plot for survival in the $\gamma R V$ trials $(A)$, in the $L V$ trials $(B)$ and in the SIN- $\gamma R V$ trial $(C)$ 


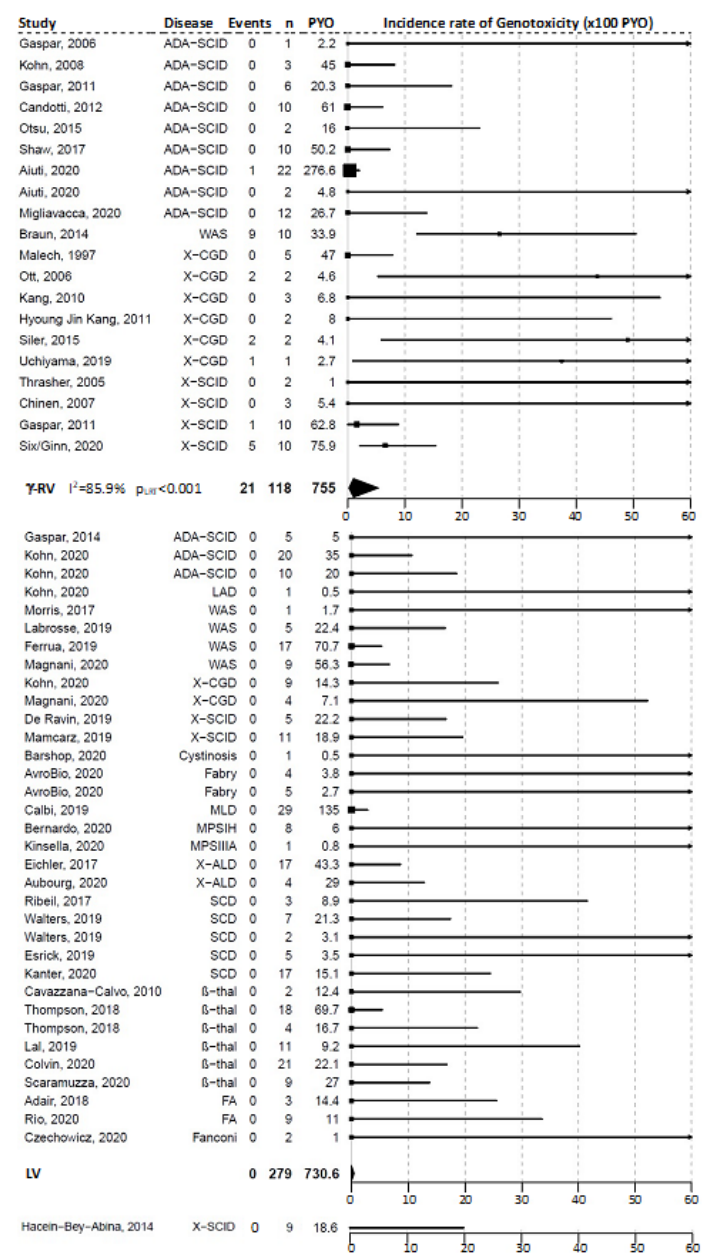

OVERALL $P^{2}=87.7 \%$ PuI $00.001 \quad 21406 \quad 1504.2$

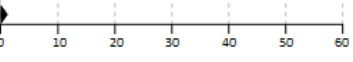

\section{Figure 3}

Forest plot for the oncogenic events in the $\gamma R V$ trials (A), in the LV trials (B) and in the SIN- $\mathrm{RV}$ trial (C) 
A)

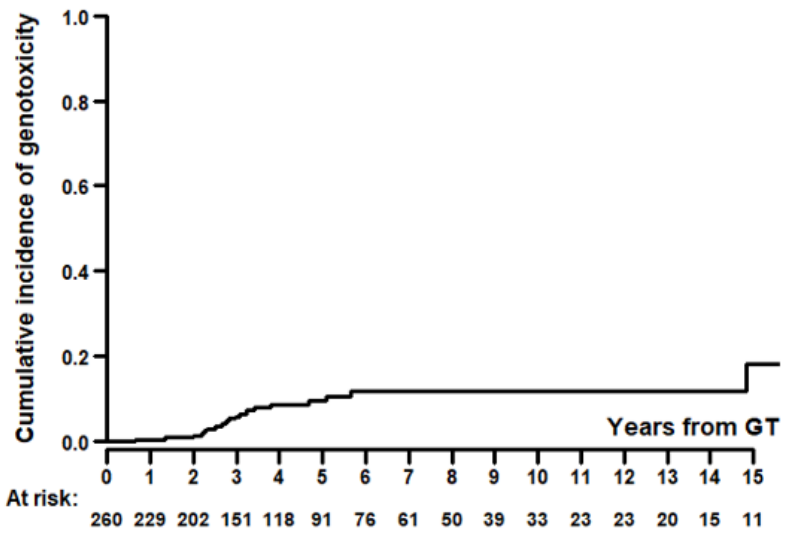

C)

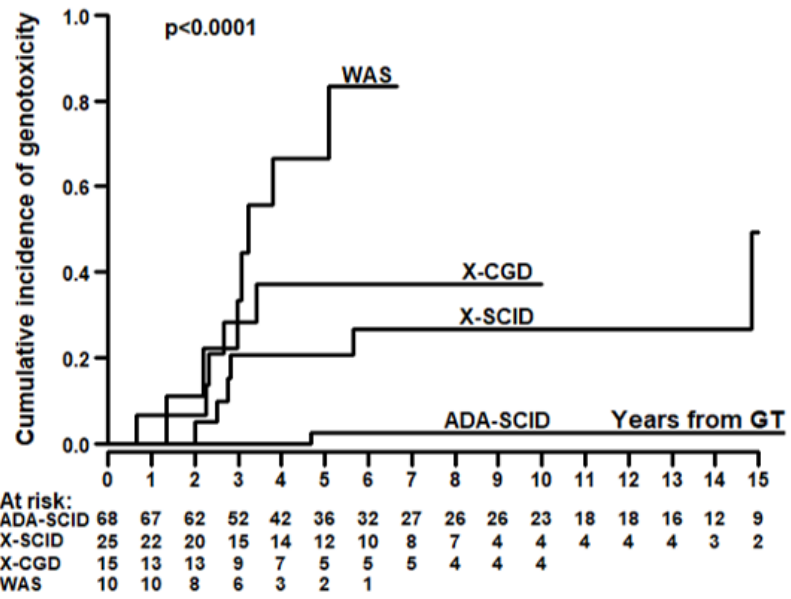

B)

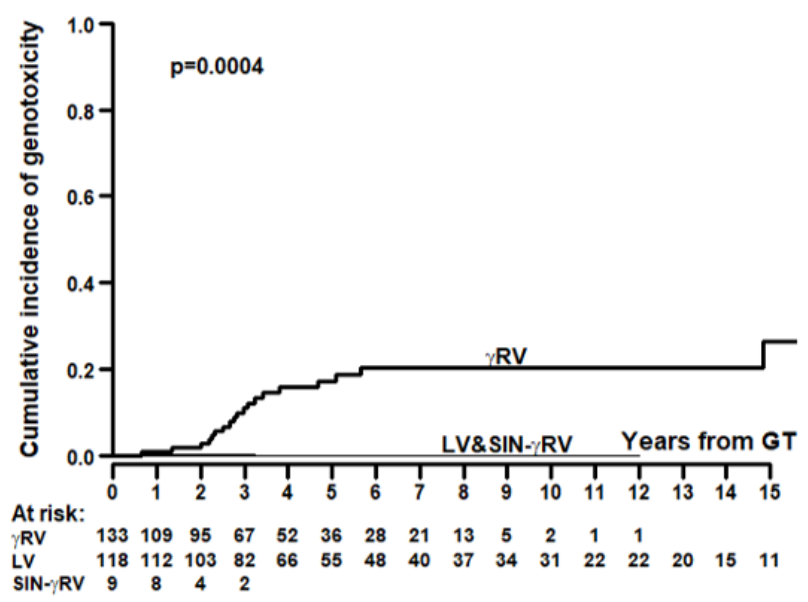

Figure 4

Crude cumulative incidence rate of genotoxicity A) overall and stratified by B) type of vector and C) disease using yRV 


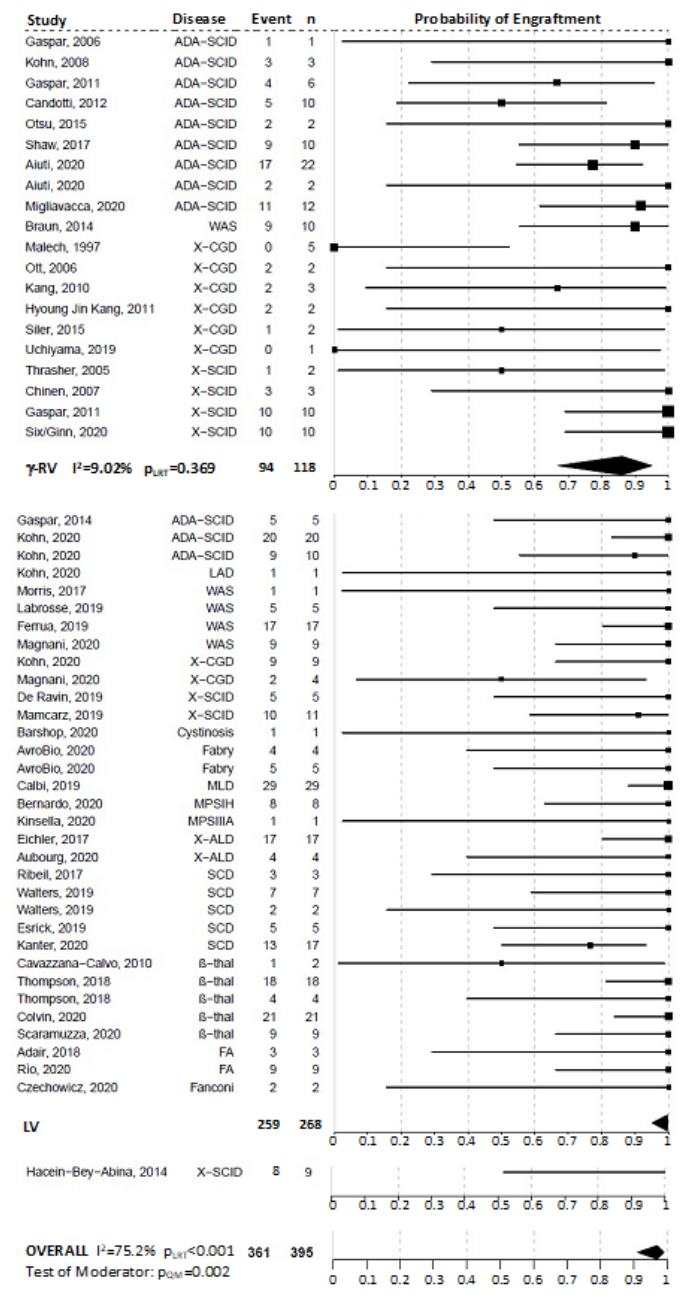

\section{Figure 5}

Forest plot for the engraftment in the yRV trials (A), in the LV trials (B) and in the SIN-yRV trial (C)

\section{Supplementary Files}

This is a list of supplementary files associated with this preprint. Click to download.

- Supplementarymaterial.pdf 